\title{
Residual effect of cattle manure application on green ear yield and corn grain yield
}

\author{
Paulo Sérgio L e Silva ${ }^{1}$; Jaeveson da Silva ${ }^{2}$; Fábio Henrique T de Oliveira ${ }^{3}$; Ana Karenina F de Sousa ${ }^{1}$; \\ Gustavo P Duda ${ }^{1}$ \\ ${ }^{1}$ ESAM, C. Postal 137, 59625-900 Mossoró-RN; ${ }^{2}$ Embrapa Mandioca e Fruticultura 44380-000 Cruz das Almas-BA; ${ }^{3}$ UFPB, 58397-000 \\ Campina Grande-PB; E-mail: paulosergio@ufersa.edu.br (corresponding author); jaeveson@cnpmf.embrapa.br; fabio@cca.ufpb.br; \\ gustavo@ufersa.edu.br
}

\begin{abstract}
The present concern about environmental degradation has produced a renewed interest in organic fertilizers, such as animal manures. In addition, the soil organic matter conservation is one of the most important limiting factors for sustainability development in semiarid regions. In a previous experiment, carried out to evaluate the direct effects of application of manure rates in corn, positive effects of this fertilization were observed on green ear yield and grain yield. It was also verified that manure increased water retention and availability, and phosphorus, potassium, and sodium contents in the soil layer from $0-20 \mathrm{~cm}$, but did not influence $\mathrm{pH}$, calcium, organic matter contents and the sum of bases. The objective of this work was to evaluate the residual effect of applied fertilization on green ear yield and grain yield in cultivars AG 9012 and AG 4051. In both cultivars, a lack of manure residual effects was verified on total number and weight of green ears; number and weight of marketable ears, either unhusked or husked; plant height and ear height; fresh and dry matter in the above-ground part; and grain yield and its components. Cultivar AG 9012 performed best with regard to characteristics employed to evaluate green corn yield, and cultivar AG 4051 was superior with reference to plant height and 100-grain weight. The cultivars were not different with respect to the other traits evaluated.
\end{abstract}

Keywords: Zea mays, organic fertilization, cultivars.

\section{RESUMO}

Efeito residual da aplicação de esterco bovino sobre os rendimentos de espigas verdes e grãos do milho

Atualmente, a preocupação com a degradação ambiental renovou o interesse por adubos orgânicos, como por exemplo, os estercos. Além disso, a manutenção da matéria orgânica no solo é um dos principais fatores limitantes ao desenvolvimento da sustentabilidade nas regiões semi-áridas. Em trabalho anterior, realizado para avaliar os efeitos diretos da aplicação de doses de esterco sobre o cultivo de milho, verificaram-se efeitos positivos dessa adubação sobre os rendimentos de espigas verdes e de grãos. Verificou-se ainda, que o esterco aumentou a retenção e a disponibilidade de água e os teores de fósforo, potássio e sódio, na camada do solo de 0-20 cm, mas não influenciou o $\mathrm{pH}$ e os teores de cálcio e de matéria orgânica e a soma de bases. O objetivo do presente trabalho foi avaliar o efeito residual da adubação realizada sobre o rendimento de espigas verdes e de grãos das cultivares AG 9012 e AG 4051. Verificou-se ausência de efeito residual do esterco sobre o número e peso total de espigas verdes, número e peso de espigas empalhadas e despalhadas, comercializáveis, altura da planta e de inserção da espiga, matérias fresca e seca da parte aérea, rendimento de grãos e seus componentes, das duas cultivares. A cultivar AG 9012 foi a melhor quanto às características relativas ao rendimento de milho verde, enquanto a cultivar AG 4051 foi superior quanto à altura da planta e peso de 100 grãos. As cultivares não diferiram no que se refere às demais características avaliadas.

Palavras-chave: Zea mays, organic manure, cultivars.

(Recebido para publicação em 28 de abril de 2005; aceito em 22 de maio de 2006)

$\mathrm{C}_{\mathrm{H}}$ orn is one of the main crops in the Brazilian Northeast. Until very recently, this plant was considered a subsistence crop and was mainly grown under dryland conditions. However, due to the support extended to irrigated agriculture by the state and federal governments, the irrigated area cultivated with corn has increased and currently the crop is even explored by large fruit producing companies for export. An interest in irrigated corn cultivation, especially during the offseason, stems from the fact that, in this period, the demand for both green ears and grain is much higher than the supply, thus raising the prices of both products.

In the region, green ears are ready for harvest in a period from 70 to 75 days. Dry grains are harvested 100 days after sowing, approximately. Therefore, it is possible to obtain almost three crops consecutively during the off-season alone, from July to December. This intensive exploitation, not only with corn, but with several other irrigated crops as well, such as melon (Cucumis melo L.) for example, has probably caused physical, chemical, and biological problems to the soils which, in general, are naturally poor. Many areas are abandoned after several cropping cycles. In the case of corn, it is possible that problems are still worse. Since there has been great interest in the trash yielded by this crop (above-ground part of the plant, without the ears) for animal nutrition, practically the entire plant is removed after each cultivation, thus contributing to exhaust the soil even more quickly. In recent years the emphasis has been shifted from individual crop to cropping system as a hole, since the responses in component crop of the cropping system are influenced by the preceding crops and the inputs applied to them (Patidar \& Mali, 2002). Organic manure, besides 
supplying nutrients to the current crop, often leaves substantial residual effect on the succeeding crops in the system (Gaur, 1982). Residual effect of organic matter added to the soil by the manure refers to the carry-over benefit of the application on the succeeding crop. Nutrients present in organic matter are not fully available to the crops in the season of its application (Ramamurthy \& Shivashankar, 1996).

In a recent evaluation of the direct effects of cattle manure on corn, it was verified (Silva et al., 2004) that manure increased green ear yield and grain yield in two corn cultivars. Cattle manure also increased water retention and availability, and phosphorus, potassium, and sodium contents in the soil layer from $0-20 \mathrm{~cm}$, but did not influence $\mathrm{pH}$, calcium, sum of bases, and organic matter contents. It would be interesting, therefore, to evaluate the residual effects of manure (Silva et al., 2004), in order to utilize the fertilization that is done in successive crops. The residual effect of organic fertilizers on yield, including cattle manure, has been found to be positive in sorghum (Patidar \& Mali, 2002), corn (Raramurthy \& Shivashankar, 1996) and Brassica juncea (L.) Czernj. \& Cosson (Rao \& Shaktawat, 2002). In corn, the residual effect of organic matter improved the plant height, dry-matter production at different stages of crop growth and yield-attributing characters of corn like number of cobs plant ${ }^{-1}$, shelling (\%), 100-grain weight, harvest index, protein contents of grain and protein yield ha ${ }^{-1}$ (Raramurthy \& Shivashankar, 1996).

The objective of this work was to evaluate the residual effects of cattle manure rates on green ear yield and grain yield in two corn cultivars, in a Argissolo Vermelho-Amarelo Eutrófico previously cultivated with corn.

\section{MATERIAL AND METHODS}

The experiment was carried out in Mossoró-RN (5 11' S latitud, $37^{\circ} 20^{\prime}$ $\mathrm{W}$ longitud, and $18 \mathrm{~m}$ height), from March to June, 2000.

The experiment was sprinklerirrigated with a $5.6 \mathrm{~mm}$ water depth and a one-day watering schedule. The water depth required was calculated considering an effective depth of the root system of $0.40 \mathrm{~m}$. Irrigation time was based on the water retained by the soil at a tension of $0.04 \mathrm{Mpa}$. The irrigations started after planting and were suspended one day before each harvest.

The soil was an Argissolo VermelhoAmarelo Eutrófico, classified as Ferric Lixisol, according to the Soil Map of the World (FAO, 1988), previously cultivated with corn. The experimental area was tilled and received, $30 \mathrm{~kg} \mathrm{~N}$ (ammonium sulfate), $60 \mathrm{~kg} \mathrm{P}_{2} \mathrm{O}_{5}$ (single superphosphate), and $30 \mathrm{~kg} \mathrm{~K}_{2} \mathrm{O}$ (potassium chloride) per hectare. The fertilizers were applied manually in furrows made alongside and below the sowing furrows. In the previous cultivation, a similar mineral fertilization was done.

Cattle manure, at rates of $0 ; 8 ; 16$; $24 ; 32$, and $40 \mathrm{tha}^{-1}$, on dry matter basis, was applied by broadcasting and incorporated to the soil with a hoe approximately 165 days before the cultivation referred to in this work. The analysis of a sample of the manure indicated: $\mathrm{pH}=7,6 ; \mathrm{Ca}=12,50 \mathrm{cmol}_{\mathrm{c}} \mathrm{dm}^{-3}$; $\mathrm{Mg}=4,70 \mathrm{cmol}_{\mathrm{c}} \mathrm{dm}^{-3} ; \mathrm{K}=6,64 \mathrm{cmol}_{\mathrm{c}}$ $\mathrm{dm}^{-3} ; \mathrm{Na}=4,32^{\mathrm{c}} \mathrm{cmol}_{\mathrm{c}} \mathrm{dm}^{-3} ; \mathrm{Al}=0,00$ $\mathrm{cmol}_{\mathrm{c}} \mathrm{dm}^{-3} ; \mathrm{P}=1245 \mathrm{mg} \mathrm{dm}^{-3}$; Organic Matter $=173,43 \mathrm{~g} \mathrm{~kg}^{-1}$. Four soil samples from each plot were collected 120 days after manure application (i.e. 45 days before corn planting); these samples were combined to make up composite samples, which were then analyzed for water retention, available water, $\mathrm{pH}, \mathrm{Ca}$, $\mathrm{Mg}, \mathrm{K}, \mathrm{Na}, \mathrm{Al}, \mathrm{P}$ and organic matter content (Brasil, 1997). Other details on manure application and composition are presented by Silva et al. (2004). Corn was planted manually on March 02 , 2000 , at a row spacing of $1.0 \mathrm{~m} \times 0.4 \mathrm{~m}$, using four seeds per pit. A thinning operation was done 20 days after planting, leaving the two more vigorous plants in each pit; the experiment was thus left with a planting density equivalent to 50,000 plants ha ${ }^{-1}$. Two cultivars were evaluated: AG 4051 and AG 9012. Cultivar AG 4051 is a tall, triple hybrid, with yellowish dent grain; while cultivar AG-9012 is a short, super early simple hybrid, with reddish flint grain.

Pest control was done by means of a deltamethrin spray $\left(250 \mathrm{~mL} \mathrm{ha}^{-1}\right)$, performed at 22 days after planting. Weed control was performed by two hoeings, conducted at 21 and 46 days after planting. After each weeding operation, the experiment was fertilized with $30 \mathrm{~kg} \mathrm{~N} \mathrm{ha}^{-1}$ (ammonium sulfate).

A completely randomized blocks design with split-plots and five replications was utilized. The manure rates, applied when the direct effect of manure was evaluated, represented plots, while cultivars represented subplots. Each subplot consisted of four $6.0 \mathrm{~m}$ long rows. The usable area was considered as the space occupied by the two central rows, with the elimination of one pit at each end.

One of the usable rows was utilized for green ear yield assessment. In this row, the total number and weight of unhusked green ears and the number and weight of marketable green ears, either unhusked or husked, as well as fresh and dry matter mass of the above-ground part, were evaluated. Marketable unhusked ears were considered as those with a length above $22 \mathrm{~cm}$ and suitable appearance for commercialization (without blemishes or perforations by pests). Marketable husked ears were considered as those with a length above $17 \mathrm{~cm}$ that displayed grain set and health suitable for commercialization. In order to evaluate fresh and dry mass of the above-ground part, six plants were cut even with the ground after the green ears were harvested, and then weighed. Next, the plants were ground and a $500 \mathrm{~g}$ sample was left to dry at a temperature of $75^{\circ} \mathrm{C}$, in a forced air circulation oven, until constant weight.

In the other usable row, evaluations included grain yield and its components, and plant and ear height. Ripe ears were harvested 100 days after sowing, when the grain showed a moisture content of approximately $20 \%$. Next, the ears were husked and left to dry in the sun for approximately 72 hours, and were then threshed by hand. After weighing the grain, a $100 \mathrm{~g}$ sample was taken to estimate moisture content. Based on the moisture content thus determined, grain weight was corrected to a moisture 
Table 1. Means (of five replicates and six cattle manure rates) for corn cultivar characteristics ${ }^{1}$. Mossoró, UFERSA, 2000.

\begin{tabular}{|c|c|c|c|c|}
\hline \multirow{2}{*}{ Characteristics } & \multicolumn{2}{|c|}{ Cultivars } & \multirow{2}{*}{$\begin{array}{l}\text { Cva } \\
(\%)\end{array}$} & \multirow{2}{*}{$\begin{array}{l}\text { CVb } \\
\text { (\%) }\end{array}$} \\
\hline & AG 4051 & AG 9012 & & \\
\hline Total number of ears ha- ${ }^{-1}$ & $49,361 \mathrm{~b}$ & 51,735 a & 8 & 7 \\
\hline No. of marketable unhusked ears ha- ${ }^{-1}$ & $41,764 b$ & 46,785 a & 14 & 11 \\
\hline No. of marketable husked ears ha-1 & $34,710 \mathrm{~b}$ & 40,652 a & 18 & 14 \\
\hline Total ear weightha ${ }^{-1}$ & $12,508 b$ & $14,096 \mathrm{a}$ & 15 & 13 \\
\hline Weight of marketable unhusked ears ha ${ }^{-1}$ & $11,523 b$ & 13,386 a & 20 & 16 \\
\hline Weight of marketable husked ears ha-1 & $6,662 b$ & 7,885 a & 24 & 18 \\
\hline Plant height $(\mathrm{cm})$ & $203 a$ & $180 \mathrm{~b}$ & 10 & 8 \\
\hline Ear height $(\mathrm{cm})$ & 97 a & $94 \mathrm{a}$ & 13 & 10 \\
\hline Fresh mass of the above-ground part $\left(\mathrm{kg} \mathrm{ha}^{-1}\right)$ & $16,767 b$ & 19,179 a & 21 & 16 \\
\hline Dry matter in the above-ground part (kg ha-1) & $5,896 a$ & 5,738 a & 18 & 15 \\
\hline Grain yield $\left(\mathrm{kg} \mathrm{ha}^{-1}\right)$ & $6,133 a$ & 5,686 a & 19 & 14 \\
\hline Number of grains ear-1 & $391 \mathrm{a}$ & $401 \mathrm{a}$ & 12 & 9 \\
\hline 100 -grain weight $(\mathrm{g})$ & $35 \mathrm{a}$ & $29 \mathrm{~b}$ & 10 & 9 \\
\hline
\end{tabular}

${ }^{1}$ Means followed by the same letter are not significantly different according to the Tukey test $(\mathrm{P}>0.05)$.

content of $15.5 \%$. Ten ears were used to estimate the number of kernels/ear ${ }^{-1}$ and five samples were used to evaluate 100grain weight. After the mature ears were harvested, ten plants were taken at random from the usable area of each plot to evaluate plant height (distance from the soil level to the insertion point of the highest leaf blade) and ear height (distance from the soil level to the insertion point of the first ear).

The statistical analysis of data was done according to recommendations by Zar (1999), using the software developed by the Universidade Federal de Viçosa (SAEG, 1997).

\section{RESULTS AND DISCUSSION}

According to the soil analyses performed 45 days before planting the crop on which the present work was based, the cattle manure effects, evaluated in the soil layer at a $0-20 \mathrm{~cm}$ depth, on water retention, available water, and phosphorus content were described by the equations $\mathrm{y}=$ $4.6905+0.1171^{* * *} \times\left(R^{2}=0.88\right), \mathrm{y}=$ $47.1633-14.3375^{* *} \mathrm{x}^{1 / 2}+4.0187^{* *} \times\left(R^{2}=\right.$ $0.96)$, and $y^{2}=543.37+50.84^{\text {ns }} x+3.98^{*}$ $\mathrm{x}^{2}\left(R^{2}=0.95\right)$, respectively. In these equations, the symbols $* *,{ }^{*}$ and ${ }^{\mathrm{ns}}$ indicate significant effects at $1 \%$ and 5\% probability and no significant effect, by $t$ test, respectively. However, cattle manure did not influence $\mathrm{pH}(8.1)$, as well as calcium $\left(3.2 \mathrm{cmol}_{\mathrm{c}} \mathrm{dm}^{-3}\right)$, magnesium $\left(1.2 \mathrm{cmol}_{\mathrm{c}} \mathrm{dm}^{-3}\right)$, potassium $\left(0.2533 \mathrm{cmol}_{\mathrm{c}} \mathrm{dm}^{-3}\right)$, sodium $\left(0.25 \mathrm{cmol}_{\mathrm{c}}\right.$ $\left.\mathrm{dm}^{-3}\right)$, and organic matter contents $(8.14$ $\mathrm{g} \mathrm{kg}^{-1}$ ) (Silva et al., 2004). Therefore, the cattle manure only had a residual effect on two of the soil's physical characteristics and on phosphorus content. Other studies, that have investigated the effects of cattle manure applications on soil traits, support the present work. Manure increased soil water retention $(0-5$ and $10-15 \mathrm{~cm})$ by 5 to $48 \%$ compared with the control at most potentials between 0 and -1500 $\mathrm{kPa}$. Field soil water content was increased by 10 to $22 \%$ (Miller et al., 2002). Other authors verified similar results (Arriaga \& Lowery, 2003). There was a linear increase in the $\mathrm{P}$ content of two soils (Holanda et al., 1984). Longterm application of dairy manure at a rate of $20 \mathrm{tha}^{-1}$ increased soil inorganic $\mathrm{P}$ forms and maintained organic $\mathrm{P}$ fractions (Tran \& N'dayegamiye, 1995).

The residual effects of cattle manure were not relevant to a point where corn traits would be influenced. The means for total number of ears ha- ${ }^{-1}$, number of marketable unhusked ears ha $^{-1}$, number of marketable husked ears ha-1, total ear weight, weight of marketable unhusked ears ha-1, weight of marketable husked ears ha ${ }^{-1}$, plant height, ear height, fresh matter in the above-ground part, dry matter in the above-ground part, grain yield, number of grains ear ${ }^{-1}$, and $100-$ grain weight were: 50,$548 ; 44,274$; 37,$681 ; 13,302 \mathrm{~kg} \mathrm{ha}^{-1} ; 12,454 \mathrm{~kg} \mathrm{ha}^{-1}$; $7,273 \mathrm{~kg} \mathrm{ha}^{-1} ; 191 \mathrm{~cm} ; 95 \mathrm{~cm} ; 17,973$ $\mathrm{kg} \mathrm{ha}^{-1} ; 5,817 \mathrm{~kg} \mathrm{ha}^{-1} ; 5,909 \mathrm{~kg} \mathrm{ha}^{-1} ; 396$ and $32,0 \mathrm{~g}$, respectively. In general, manures have a low $\mathrm{C} / \mathrm{N}$ ratio and undergo rapid mineralization, especially under dry weather (means for maximum air temperature, minimum air temperature, piche evaporation and insolation, during the crop cycle, were $34.4^{\circ} \mathrm{C}, 19.4^{\circ} \mathrm{C}, 114.8 \mathrm{~mm}$ and $224.1 \mathrm{~h}$ month $^{-1}$, respectively) and high soil moisture (as provided by irrigation and $525 \mathrm{~mm}$ of precipitation), and under good aeration and drainage conditions. The soil of the experimental area presents around $940 \mathrm{~g} \mathrm{~kg}^{-1}$ of sand and a total porosity of $28 \%$ at the $0-20 \mathrm{~cm}$ depth, in the Ap horizon (Mota, 2004). The fact that the residual effects of manure are dependent upon all these variables probably explains the discrepancies among authors on the effects of cattle manure on yield of various crops. The residual effect depends, for example, on the trait under study, the year when evaluation is done (Raramurthy \& Shivashankar, 1996), and the sequence of crops grown (Minhas et al., 1994). Under irrigation, the increases in soluble ion contents due to manure application are smaller than those obtained without irrigation (Hao \& Chang, 2003).

The soil analysis mentioned, performed 45 days before planting the crop on which the present work was based, indicated that, on average, relative to the first cultivation (Silva $e t$ al., 2004), the following occurred: increases in $\mathrm{pH}$ (15.7 percentage points, $\mathrm{pp})$, and contents of $\mathrm{Ca}$ (60 pp), $\mathrm{Mg}$ (140 pp), K (177 pp), Na (2400 pp), and Organic Matter (18 pp). As mentioned before, phosphorus content was influenced by cattle manure doses. Soil fertility level may also influence the crop's response to manure, and a small response, or even the absence of response, is expected in very fertile soils.

Therefore, there was a direct effect of cattle manure on green ear yield and grain yield (Silva et al., 2004), but not of the residual effect, on these traits. An absence of cattle manure residual effect 
on corn grain yield has been observed by other authors (Minhas et al., 1994). However, in other papers (Sharma et al., 1996), direct and residual effects on grain yield have been observed. In works where cattle manure has shown a residual effect on grain yield or on the yield of plant aerial parts, in general, a residual effect of manure on the absorption of nutrients was verified (Sharma et al., 1996; Brar et al., 2001; Raramurthy \& Shivashankar, 1996). This is associated to manure quality, mineralization intensity and utilization by a given crop.

Cultivar AG 9012 was superior to cultivar AG 4051 in all characteristics used to evaluate green ear yield, but no difference between them was observed with regard to dry grain yield (Table 1). This finding supports the observation (Silva et al., 1997; Silva et al., 1998) that different cultivars may be required, depending on the purpose for which the crop is being explored, green ears or grain. Despite the superiority of cultivar AG 9012 in number of mature ears ha-1 (estimated by the total number of green ears), the other cultivar showed a higher 100 -grain weight value. The compensation between these two yield components would explain the behavior similarity between them in relation to grain yield, since they were not different with respect to number of kernels/ear, the other yield component.

The absence of a residual effect of manure may mean that irrigated corn producers, at least in some areas of the Brazilian Semiarid Region, in soils without aeration restrictions and during a second cultivation, will not bring considerable benefits from organic fertilization made in a previous cultivation, because of the rapid mineralization of the cattle manure applied. The producer would have to apply cattle manure again and/or improve mineral fertilization, to maintain higher productivity levels.

It can thus be concluded that cattle manure only had a residual effect on soil water retention, available water, and soil phosphorus content in addition, there were no residual effects on total number and weight total number and weight of green ears, number and weight of marketable unhusked and husked ears, plant height and ear height, fresh and dry matter of the aerial part, and grain yield and its components for both cultivars. Cultivar AG 9012 performed best with regard to characteristics employed to evaluate green corn yield, and cultivar AG 4051 was superior with reference to plant height and 100-grain weight. The cultivars were not different with respect to the other traits.

\section{REFERENCES}

ARRIAGA FJ; LOWERY B. 2003. Soil physical properties and crop productivity of an eroded soil amended with cattle manure. Soil Science 168: 888-899.

BRAR BS; DHILLON NS; CHHINA HS. 2001. Integrated use pf farmyard manure and inorganic fertilizers in maize (Zea mays). Indian Journal of Agricultural Sciences 71: 605-607.

BRASIL, Ministério da Agricultura. 1997. Manual de métodos de análise de solo. 2 ed. Rio de Janeiro: EMBRAPA/CNPS. 212p.

FAO. 1988. Soil map of the world; revised legend. Rome: UNESCO. 119p.

GAUR AC. 1982. Review of soil research in India. In: INTERNATIONAL CONGRESS OF SOIL SCIENCE, 12. New Delhi. Proceedings... New Delhi: International Society of Soil Science. p.278-305.

HAO X; CHANG C. 2003. Does long-term cattle manure application increase salinity of a clay loam soil in semi-arid southern Alberta. Agriculture, Ecosystems \& Environment 94: 89-103.

HOLANDA JS; TORRES FILHO J; BEZERRA NETO F. 1984. Alterações na fertilidade de dois solos adubados com esterco de curral e cultivados com caupi. Revista Brasileira de Ciência do Solo 8: 301-304.
MILLER JJ; SWEETLAND NJ; CHANG C.2002. Hydrological properties of a clay loam soil after long-term cattle manure application. Journal of Environmental Quality 31: 989-996.

MINHAS RS; DUTTA MN; VERMA TS. 1994. Effect of phosphorus, animal manure and lime on crop yields in a potato-maize-potato-wheat cropping sequence in north-west Himalayan acid Alfisols. Journal of the Indian Potato Association 21: 142-146.

MOTA JCA. 2004. Caracterização física, química e mineralógica, como suporte para o manejo, dos principais solos explorados com a cultura do melão na Chapada do Apodi $-R N$. Fortaleza: UFC. 96p. (Dissertação mestrado).

PATIDAR M; MALI AL. 2002. Residual effect of farmyard manure, fertilizer and biofertilizer on succeeding wheat (Triticum aestivum). Indian Journal of Agronomy 47: 26-32.

RAMAMURTHY V; SHIVASHANKAR K. 1996. Residual effect of organic matter and phosphorus on growth, yield and quality of maize (Zea mays). Indian Journal of Agronomy 41: 247-251.

RAO SS; SHAKTAWAT MS. 2002. Residual effect of organic manure, phosphorus and gypsum application in preceding groundnut (Arachis hypogea) on soil fertility and productivity of Indian mustard (Brassica juncea). Indian Journal of Agronomy 47: 487494.

SAEG. 1997. Sistemas para análises estatísticas, 7.0. Viçosa: Fundação Arthur Bernardes./UFV/ DBG.

SHARMACM; KAUL S; BHARDWAj SK. 1996. Effect of Udaipur rock phosphate alone and in combination with organics on maize (Zea mays)-wheat (Triticum aestivum) production under acid soil. Indian Journal of Agronomy 41: 505-506.

SILVA J; SILVA PSL; OLIVEIRA M; SILVA KMB. 2004. Efeito de esterco bovino sobre os rendimentos de espigas verdes e de grãos de milho. Horticultura Brasileira 22: 326-331.

SILVA PSL; BARRETO HEP; SANTOS MX. 1997. Avaliação de cultivares de milho quanto aos rendimentos de grãos verdes e secos. Pesquisa Agropecuária Brasileira 32: 63-69.

SILVA PSL; SILVA KMB; SILVA NL; DINIZ FILHO ET; SANTOS MX. 1998. Rendimentos de grãos verdes e secos de cultivares de milho I. Período 1985-90. Revista Ceres 45: 89-115.

TRAN TS; N'DAYEGAMIYE A. 1995. Longterm effects of fertilizers and manure application on the forms and availability of soil phosphorus. Canadian Journal of Soil Science 75: 281-285.

ZAR JH. 1999. Biostatistical analysis. 4.ed. Upper Saddle River: Prentice Hall. 663p. 